\title{
Starting from the Beginning: On Building a School and Community-Based System Supporting the Gifted ${ }^{1}$
}

\author{
Hanna David \\ School of Education, Tel Aviv University, Jerusalem, Israel.
}

\section{Distinguished Ladies and Gentlemen}

I feel honoured and privileged to be invited to deliver the 2011 Raphael Nosike Lecture courtesy of the Raphael Nosike Foundation(RNF) and African Association for Teaching and Learning(AATL).

Special education for the gifted has become necessary when more countries and societies have "joined the club" not only as believers in compulsory education but also as actively practicing it. This process has been accelerated with the increasing population strata understanding the importance of basic and post-elementary education, and showing willingness to postpone the financial benefit of the younger generation joining the work force. The result has been the rewarding of the more educated socially and politically, in addition to the increasing salary gap between the more and the less educated. At this point it was made clear that the time of special education for the more able has come.

\section{Introduction}

The distribution of intellectual abilities, areas of interest, inner motivation, and persistence to "make it" in spite of outer and inner difficulties is equal among all nations and societies. Thus, it is of special importance in less-advantaged countries to have the double-edged benefit of those who are more talented. First, such people are the most-valued asset of society; they can contribute both to the welfare of many others, and to the economics of the country. Second, gifted children and youths need to fulfill their high potential in order to become highly qualified adults for their own physical, mental and financial well-being, sense of completeness, and satisfaction. Education for the gifted is indeed a win-win situation.

The preliminary stages needed for starting a whole system of gifted education are:

1. Awareness of the necessity of gifted education being available to all suitable students;

2. Reasons for the special importance of having gifted education in Nigeria

I. Compulsory education is spreading

II. The Gaussian distribution is a mathematical-statistical fact, valid everywhere and in all times. Thus, the gifted of Nigeria should benefit from special education exactly as has been done in many other countries for up to 10 decades.

3. Adopting an identification-of-giftedness system with minimal cost and maximal effectiveness

I. The need to learn from history

II. The need to learn the main existing programs

III. The need to learn the basic giftedness models

4. Starting teacher education courses in all aspects of giftedness for kindergarten, elementary, junior

\footnotetext{
${ }^{1}$ Full text of the 2011 raphael nosike lecture delivered during the first international conference on teaching, learning and change organised by african association for teaching and learning in association with raphael nosike foundation held at claude ake hall, federal college of education (technical), omoku-rivers state, nigeria, september 7, 2011.
} 
high school and high school teachers;

5. Offer health and education experts to participate in a variety of activities for identifying and nurturing the gifted. These experts will include psychologists, school counselors, headmasters and headmistresses, nurses and pediatricians.

6. Building a dynamic evaluation system that will produce and supply advancement reports at every stage of the work, in order to be able to make the needed changes immediately in case the results or outcomes do not reach the highest possible levels.

These stages are to be described at length.

\section{Awareness of the Necessity of Gifted Education Being Available to all Suitable Students}

One of the main problems of establishing gifted education is the comparatively low awareness of its need. The tendency to ignore the needs of those who "will make it anyway" - namely, the gifted - has deep roots in the history of giftedness. Linzer Schwartz (1994) has dedicated a whole book to presenting evidence that investing time, energy and money in the suitable educational opportunities for the gifted is not undemocratic. Linzer Schwartz had rather shown that small initial commitment will yield exceptional future leaders. Everyone will benefit from the rich return on such an investment. She describes the types of giftedness and gives nine categories of options available for enhancing the educational experiences of gifted students and how these options can be modified to meet individual needs. Some of these options cost virtually nothing while others fly in the face of current practices.

Lack of awareness of the needs of the gifted is has been found among Australian teachers as well (Chessman, 2005). The finding of this study was that teacher training was essential to identify and cater for the gifted and talented. The first stage Chessman suggested had been to raise the awareness to the needs of the gifted in order to be able to nurture them emotionally and academically.

\section{Reasons for the Special Importance of Having Gifted Education in Nigeria}

\section{Compulsory Education is Spreading}

The need for special education for the gifted started in the 20th century, when more and most children joined the growing public education system that had eventually become free as well as compulsive. Special education for the gifted becomes necessary when a country or a society joins the club not only as a believer in compulsory education but also as actively practicing it. Nigeria has obviously reached that point. Literacy rate in Nigeria is accelerating amazingly: while among people over 80 only $13 \%$ are literate, among persons aged 15 to 19 years - those who were of primary school age in the 1990 s - the literacy rate is $70 \%(\mathrm{CIA}$ Report, 2010). In just a few years more the literacy rate in Nigeria will close the gap with most developed countries. By preparing the infrastructure of gifted education in the immediate future the more educated and more talented are to be rewarded socially and financially, and the country is to benefit from their fulfilled abilities in all areas.

From the psychological point of view, that of the individual child, the benefit of gifted education is multifocal. Vondráková, \& Palková (2007) mentioned that in many cases a gifted child, who prior to the law of compulsory education could have studies at her or his own pace, must adjust to the rather slow learning in class, and boredom might cause her or him lose interest, hindering the ability to activate the potential to its full power. Cooper, \& Sureau (2007), in their article that defends homeschooling, mention that parents of the gifted quite often have difficulties finding suitable public education for their children and thus feel they have no choice but to transfer to homeschooling. The other side of compulsory education is that while before it was practiced, many slow learners, children with disabilities of all kinds and those who were not particularly interested in learning had a choice of not learning, and thus children who did attend school were usually of 
very good ability, and highly motivated. This enabled more gifted children to participate in the usual class activities that were, in many cases, more challenging (Barrington, 1968). Since the implementation of the compulsory education law, more gifted children have found school more boring and less challenging, and are in need of special classes.

\section{The Gaussian Distribution is a Mathematical-Statistical Fact, Valid everywhere and in all times. Thus, the Gifted of Nigeria should Benefit from Special Education exactly as has been done in so many other Countries for up to 10 Decades.}

About 15 years ago I taught a course on gifted education in a teachers' college located in the Israeli periphery, where the vast majority of the population was non-professionals, the parents had low aspirations for their children and the teachers were mostly those who could not find a teaching position in a more desirable region. I started the course by asking all students to sit in a large circle, and then I approached the one sitting at my right and asked: "Tell me about a gifted child you have met". She answered immediately: "I have never met any gifted child". "Would you care to think a little bit?" I asked. "No", was the answer. "Maybe I will get back to you later", I said. I approached the student sitting at her right and asked the same question; the answer was the same. A slight change came when I got to the seventh student: "Does it have to be a student of mine?" "No", I said. "Any gifted child will do". And then finally came the first short description - of a 7-year-old girl who was singing beautifully, already an expert belly-dancer who was invited to all weddings, engagement parties and bar-mitzvahs of her relatives and neighbors, and an extremely friendly person, whom everybody loved, who had a "heart of gold" and was admired by the young and the old alike. When the student finished the description, student number 3 asked shyly: "Can I tell about my gifted child now"? And indeed - he told us about his 3-year-old son, who already started reading! That class helped everybody realize that gifted children were everywhere. A lot of them. Of all ages, in all neighborhoods, but it required a loving, caring and understanding adult to notice them, let alone to nurture them!

\section{Adopting an Identification-of-Giftedness System with Minimal Cost and Maximal Effectiveness}

Identification of giftedness has been one of the main problems in gifted education since the beginning of the 20th century.

\section{The Need to Learn from History}

The most famous longitudinal study of giftedness has been The Terman Studies of Giftedness. Terman had screened 1444 "original Terman children" in California in 1921, and an "additional" 84 (altogether: 856 males and 672 females), whose average age was 10 , and that group had been studied until the end of the 20th century (Burks et al., 1930; Holahan, \& Sears, 1995; Janos, 1987; Oden, 1968; Seagoe, 1975; Sears, 1977, 1984; Sears \& Barbee, 1975; Terman, 1925, 1930, 1954a, 1954b, 1959; Terman \& Oden, 1935, 1947, 1951,1954; Terman et al., 1990). In spite of the fact that their minimal IQ had been 135, they had not fulfilled their giftedness, namely - had inferior achievements in comparison to what could have been expected from their very high inborn abilities and nurturing. For example: not even one of the Terman children received the Nobel Prize, but two of the children who had not made it in the Terman screening process did: the late William Shockley, who shared the 1956 physics prize for helping invent the transistor, and the late Luis W. Alvarez, who won the 1968 physics prize for his work that proved the existence of some subatomic particles (Shurkin, 1992). There has not been even one political or social leader who was a part of the Terman research, neither a Pulitzer Prize winner nor a Picasso (Paddock, 1995). The vast majority of the Terman Kids are already dead - had they been alive their mean age would have been 100 . However, whether the cause of the limited achievements is mainly the problematic identification process, or it is just that the way of 
"real" success is not always closely connected to the IQ - we must be a little more modest about our expectations from gifted children, whatever our preferred screening method is.

The first class for gifted children was opened by Leta S. Hollingworth in New York in 1922 (e.g. Hollingworth, 1926, 1942; Stanley, 1990). Though accepting a teaching position in educational psychology at Columbia Teachers College in 1916 and holding that position for the rest of her life, Hollingworth served also as the principal of what had later become the New York School for Exceptional Children.

\section{The Need to Learn the Main Existing Screening Programs}

In order to reach a friendly interface for the identification and selection of gifted students, there are a number of stages involved. An appropriate screening program should be chosen. Such a program must take into consideration variables such as: the population size, the language/s of the screening tests, the financial investment available as well as additional future resources, the availability of professionals required for the screening process, and the public opinion regarding the investment of public money in nurturing but a small minority of the children. At the initial stage the gifted must be identified, tested and selected. They should then be nourished, guided and counseled. The current project proposes the development of a process by integrating qualitative and quantitative elements for the identification and selection of gifted students within the educational system in Nigeria. It proposes a method capable of going through the identification / selection stage of such a program. The basic proper program, tailored as "Haute couture" rather than "one size fits all", is to be chosen from the existing programs, but it should be implemented after making all necessary changes: linguistic, financial, and cultural.

\section{The Need to Learn Basic Giftedness Models from Around the World}

As gifted education has so many forms and procedures, in so many parts of the world, let us survey the most well spread, discussed in the literature, and perceived as effective.

In North America

\section{In the US}

Extracurricular services for the gifted and talented had started in the US almost 100 years ago, and became a national interest especially after the Soviet Union's launch of Sputnik in the late 1950s. At that time the American government had experienced a public humiliation, when the communist education, espousing excellence, had "beaten" the capitalist though egalitarian Western one. Further legislative efforts by the federal government have been implemented in the early 1970s; at about that time a variety of definitions of giftedness had been expanded, and optional programs were made available for gifted students (Marland, 1972).

In spite of the fact that the first series of intelligence tests, the Binet-Simon tests, were translated into English from French, the development of gifted education in Europe had lagged behind that of the US (Wolf, 1969). However, some of the best identification systems for giftedness have been developed in Europe (e.g. Heller, 2005; Heller, \& Schofield, 2000; Heller et al., 2005; Mönks, \& Pflüger, 2005; Persson, et al., 2000), as well as programs for talented students in a variety of other areas (e.g. Reichert, 2007).

Until now, sociological factors and small budgets have not allowed such services to develop for the gifted and talented students. Instead, special attention has been given to the disadvantaged, the handicapped, and the less gifted. It is only recently that societies have started to appreciate the benefits of gifted and talented child development, achievements and leadership. Therefore, it is necessary for a society to find the appropriate methods of helping such children to reach their full potential. Let us review some of the main existing programs. There are many models for the identification and nurturing of the gifted. We shall hereby describe 
three of the most well known American ones.

Renzulli's Schoolwide Enrichment Model (SEM) (Renzulli, 1978, 1986; Renzulli \& Reis, 1985, 1994, 1997). Here is the Three-Ring Model describing it:

Renzulli's Three-Ring Model (Renzulli, 1978)

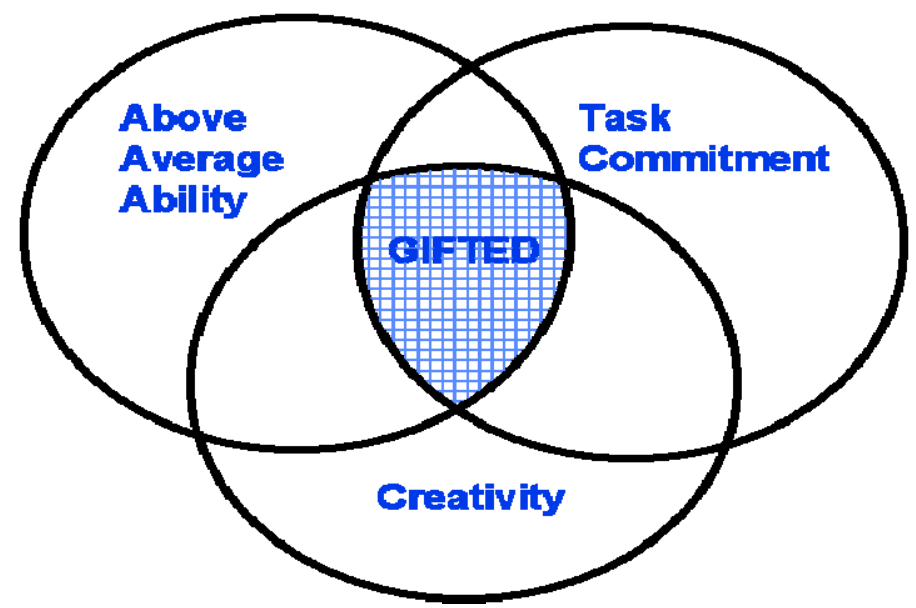

Renzulli's definition affirmed the now widely accepted assumption - that giftedness was multi-dimensional and could be sited in any area of human ability:

Giftedness consists of an interaction among three basic clusters of human traits - these clusters being above average general abilities, high levels of task commitment and high levels of creativity. Gifted and talented children are those possessing or capable of possessing this composite set of traits and applying them to any potentially valuable area of human performance. Children who manifest or are capable of developing an interaction among the three clusters require a wide variety of educational opportunities or services that are not ordinarily provided through regular instructional programs (Renzulli, 1978, p. 261).

However:

- 'above average' meant among the top $15-20 \%$ of people in any area of human endeavour (Renzulli, 1986).

- 'task commitment' - 'perseverance, endurance, hard work, dedicated practice, self-confidence and a belief in one's ability to carry out important work' (Renzulli, 1986, p. 69). Task commitment is a very specific form of motivation focused on the task in hand.

- none of the three 'clusters' of traits noted above is by itself sufficient to define a child as gifted:

It is the interaction among the three clusters that research has shown to be the necessary ingredient for creative/productive accomplishment (Renzulli, 1978, p. 182).

Based on the characteristics of creative and productive adults, the Renzulli model might not identify accurately the potential for high achievements. The model emphasizes task commitment and does not take into consideration children with a lesser level of motivation or ambition. It might also leave "out of the gifted circle" children who have not yet encountered challenges that might make them "stretch their limits". In addition, the Renzulli model might keep out students with a comparatively low level of creativity, or students whose creativity has not flourished yet.

Tannenbaum's 'sea star' model of giftedness (1983) addresses the relationships between ability and achievement - 'the links between promise and fulfillment' (Tannenbaum, 1983) - and clearly identifies the roles of both the child's personality and the environment in which he or she is brought up and educated.

- Relationship between ability and achievement

- Identifies role of personality AND environment

- Based on highly able children \& teenagers 
- $\quad$ Giftedness of children is potential for adult activity

- 5 internal \& external variables (points on star)

- All 5 must be present for ability to translate into achievement

- $\quad$ Producers (develop) Performers (interpret/recreate)

- Creativity or proficiency

- General ability: testable general intelligence, different levels for different accomplishments

- Special ability: capacity/affinity for particular work plus capacity to think

- Non-intellective factors: motivation, self-concept, persistence, mental health etc.

- Environmental: societal choices, family, peers, school, community, economic, social, legal, political institutions

- $\quad$ Chance: unpredictable events, teachers, job market

- $\quad$ Static and dynamic elements

\section{In Canada}

Gagné's Differentiated Model of Giftedness and Talent (Gagné, 2004, 2009)

Gagné's model differentiates between giftedness and talent. According to him, giftedness is the possession and use of inborn abilities, in at least one ability domain, which places a child at percentile 85 of his or her age peers. Talent is the superior mastery of developed abilities and knowledge, in at least one field, that places a child's achievement at percentile 85 of his or her age peers.

The attached diagram shows the 5 aptitude domains of the Gagné model: intellectual, creative, socioaffective, sensorimotor and "others". These natural abilities are easily observed in young children, and are needed for all tasks children have to accomplish - academic and creative, technological, artistic, social and emotional as well as athletic.

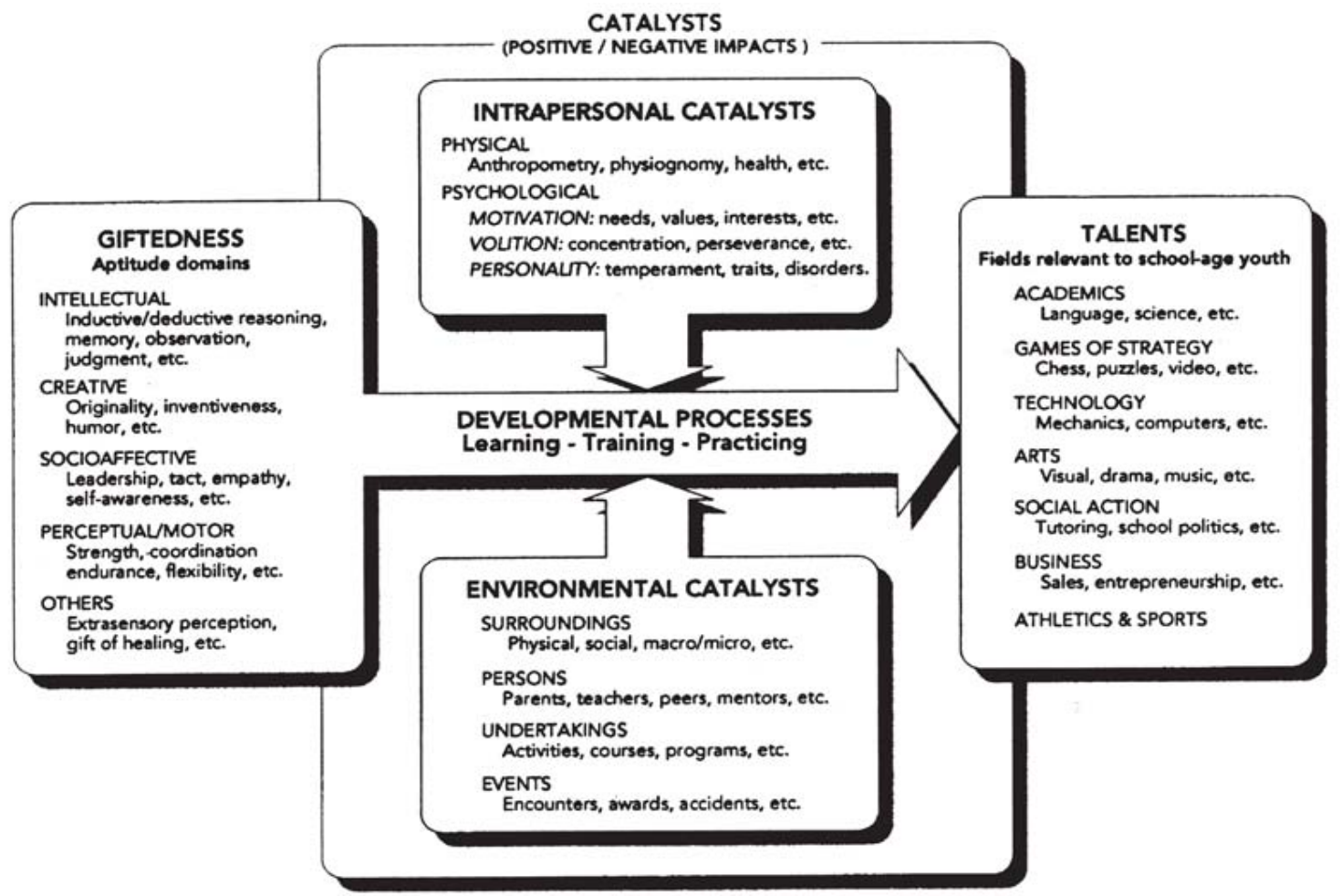

Figure 1.1. Gagné's Differentiated Model of Giftedness and Talent (DMGT)

Note. From "Is There Light at the End of the Tunnel?," by F. Gagné, 1999, Journal for the Education of the Gifted, 22, p. 231. Copyright (C)1999 by The Association for the Gifted. Reprinted with permission. 
According to Gagné, it is necessary to be gifted in order to become talented. In order for a gift to become a talent, training and practicing is necessary. Two types of catalysts, intrapersonal and environmental would make the difference between gifts that do or do not develop into talent. The intrapersonal catalysts include motivation and temperament; the environmental catalysts include the surroundings: e.g. geography, demography, sociology; persons: e.g. family size, personality and parenting style; influencing others: e.g. teachers, mentors, and significant events: e.g. death in the family, moving to another country. All these components are combined into the "developmental process", and at the end of the process, depending also on chance, the person would either be labeled as "talented" or not.In addition, there have been programs for identifying and nurturing the gifted on all continents.

\section{In Europe}

The Munich Model of Giftedness (Heller, 2005; Heller et al., 2005)

The Munich Model of Giftedness by Kurt A. Heller, Christopher Perleth and Ernst A. Hany uses a multifactorial approach to explain giftedness and its development. The model is based on four interdependent multifactorial dimensions: talent factors (relatively independent), resulting performance areas, personality factors, and environmental factors; the latter two moderating the transition from talent (gifts) to performance.

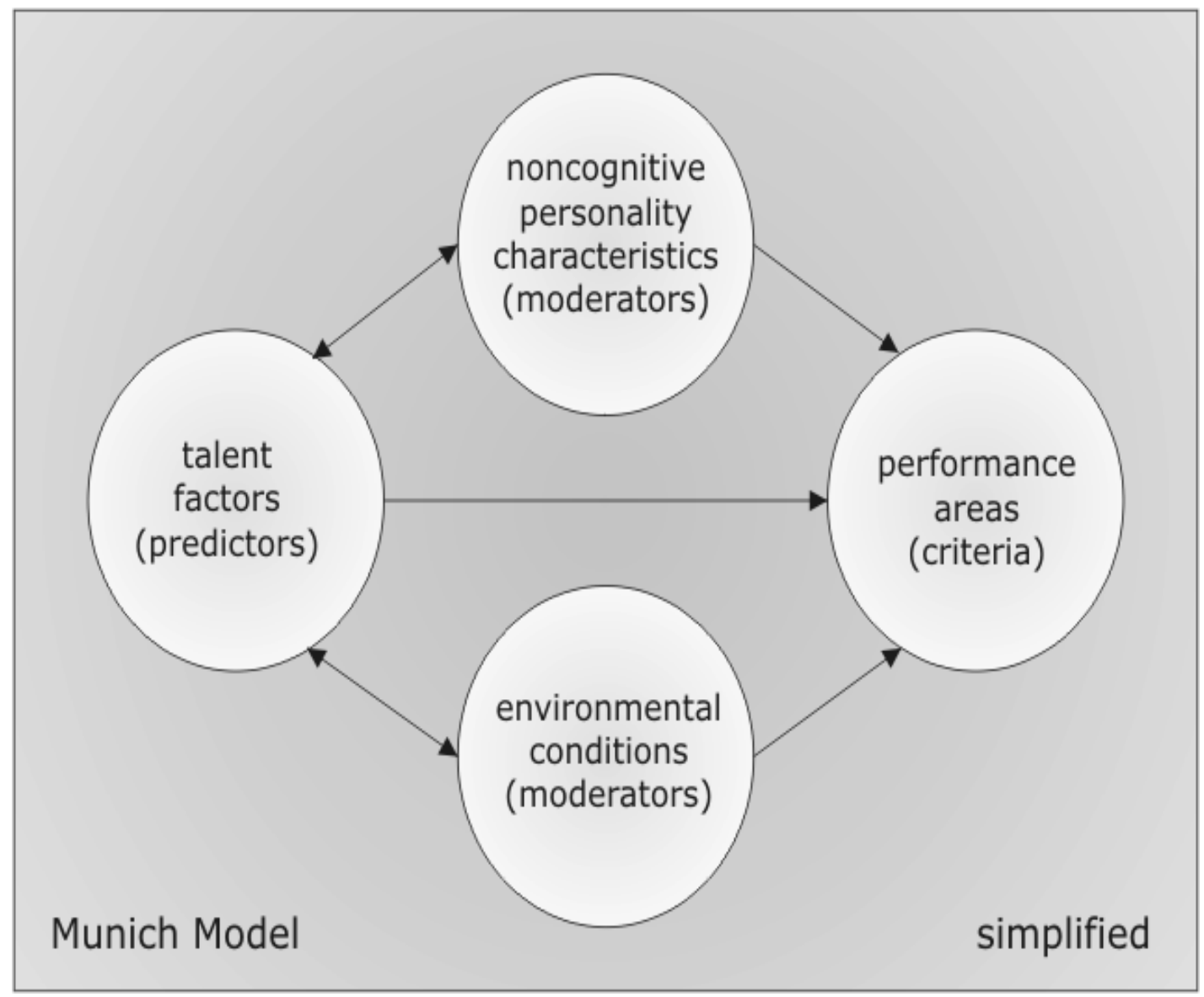




\begin{tabular}{|c|c|}
\hline $\begin{array}{l}\text { In the Munich model the talent factors contain the } \\
\text { following seven abilities: } \\
\text { - } \quad \text { intellectual abilities, } \\
\text { - } \quad \text { creative abilities, } \\
\text { - } \quad \text { practical competence, } \\
\text { - artistic abilities, } \\
\text { - musicality, } \\
\text { - } \text { and psycho-motoric skills. }\end{array}$ & $\begin{array}{l}\text { The eight performance areas are: } \\
\text { - } \text { mathematics, } \\
\text { - } \text { natural sciences, } \\
\text { - } \text { computogy, } \\
\text { - } \text { arts (music, painting), } \\
\text { - } \quad \text { languages, } \\
\text { - } \quad \text { athletics, sports, } \\
\text { and social relationship. }\end{array}$ \\
\hline $\begin{array}{l}\text { Important noncognitive personality characteristics } \\
\text { moderated by the talent factors and moderating } \\
\text { talent and performance are: } \\
\text { - } \quad \text { coping with stress, } \\
\text { - } \text { achievement motivation, } \\
\text { - learning and working strategies, } \\
\text { - control expectations, } \\
\text { - hope for success versus fear of failure, } \\
\text { - thirst for knowledge, } \\
\text { - } \text { and self-concept. }\end{array}$ & $\begin{array}{l}\text { Important environmental conditions moderated by the } \\
\text { talent factors and moderating talent and performance } \\
\text { are: } \\
\text { - } \quad \text { family climate, } \\
\text { - } \text { number of siblings and sibling position, } \\
\text { - } \text { home environmental stimulation, } \\
\text { - demands and performance made at home, } \\
\text { - } \quad \text { familiar learning environment, } \\
\text { - classroom climate, } \\
\text { - } \quad \text { quality of instruction, } \\
\text { - differentiated learning and instruction, } \\
\text { - } \quad \text { educational style, } \\
\text { - } \quad \text { social reactions to success and failure, } \\
\text { - } \quad \text { and critical life events. }\end{array}$ \\
\hline
\end{tabular}

From: Sternberg, \& Davidson, 2005, pp. 147-170

\section{In South-East Asia}

The system of identifying the gifted in Singapore has been described at length on the official government website: Gifted Education Programme (2011). Lih \& Anku (1996) have given their perspectives on it. The system is based on a 2-circle round: just like in Israel (David, 2008). $3^{\text {rd }}$ grade students are examined in their classes, and those with the best achievements in language, math and general knowledge are invited for the "second round" examination, of which $1 \%$ of the students are chosen for gifted classes. However, at the end of elementary school there is another round of identification, and youth who have not made it to percentile 99 at age 9 have another opportunity to be chosen for the gifted classes.

\section{The 3 Main Components of the System are:}

\section{Selection of Teachers}

Teachers are selected for the GEP after a process of interview and classroom observation. The qualities which the GE Branch looks for in a teacher include strength in subject content, creativity, flexibility and proficiency in teaching. 


\section{Basic Training of Teachers}

The selected teachers are then required to undergo a foundation course where they are exposed to the concept of education for the gifted, the principles of education for the gifted, and the principles of curriculum differentiation and affective education. This course is followed by a GEP Annual Conference whereby all GEP teachers attend workshops, review the GEP curriculum, and plan for the new academic year.

\section{In-service Training}

The training and development of GEP teachers takes place on the job. GE Branch officers help the teachers via developmental supervision and regular meetings which discuss matters relating to the GEP curriculum and teaching strategies. The GE Branch also organizes courses that are conducted by GE Branch officers, gifted education specialists and overseas consultants. Examples of such courses are the Innovation Programme Workshop for primary GEP teachers, Basic Counselling Skills for Teachers of the Gifted and many more. GEP teachers and officers are also sent on overseas attachments or sent to attend overseas courses (Lih and Anku, 1996).

In addition to the principle described in Lih and Anku (ibid), attention had been paid to psychological and social components that prevent many gifted students from succeeding. Teo \& Quah (1999) had studied the effects of an experimental intervention program including testing pupils' knowledge of the self, volition, consultation, time management and stress management on gifted secondary school students. The results showed that the influence was not on academic achievements, but rather on personal development of the students. Given the fact that many gifted students do not completely fulfill their abilities because of intrinsic and external problems and inhibitions they are not able to overcome, it seems that social/psychological support, given to all gifted students, is indeed highly recommended.

Many more programs for identifying and nurturing the gifted exist in other South-Eastern countries, For example: in Hong Kong: Wu (2009), David (2009c); In China: David \& Wu, (2009a); in South Korea: Wollam (1992). Reviewing all of them is beyond the scope of this paper.

\section{In Australia and New Zealand}

One of the most developed systems for identification and nurturing the gifted, based mainly on public money, has been developed in Australia, by the Australian Department of Education and Early Childhood development (2011). The program covers all gifted education areas - psychology of the gifted, counseling the gifted ad teaching the gifted, and offers pre- and in-service training for teachers, intensive courses held during concentrated weekends and school vacations, as well as e-courses at a variety of levels in all positions of the education system.

New Zealand has also developed some good programs for the gifted, tailored for its highly varied population. For example: the reading program of Bethlehem College (Sanders, 1994; Vosslamber, 2002). In addition, many other New Zealand identification and nurturing programs have been applied in the public system (e.g. Hartley, 1996; McAlpine, 1996; Ministry of Education, 2000; Townsend, 1996).

\section{In Europe}

Until the end of the 20th century, most giftedness books had been written from either an American or European perspective. Fortunately, this has changed, and the books published in the last decades either have been international collections (e.g.; Heller et al., 2000; Heller, \& Schofield, 2008; Persson et al., 2000; Shavinina, 2009) or have focused on other parts of the world, such as China or the Middle East (e.g. David et al., 2009). 


\section{In the USSR (Before 1990) and the New Republics}

Gifted education as such had not been practiced in the Soviet Union, where the dominating belief was that of equality. However, special programs for the nurturing of talented children and youth in all possible fields helped the ex-USSR and its partner countries, especially Poland and East Germany, be the habitat of the highest achieving people in mathematics, science and technology, sports and dancing, chess and even some of the most original theories in the humanities (e.g. Russian Structuralism) and social sciences (e.g. Dabrowski's Theory of Positive Disintegration, Dabrowski, 1964; Dabrowski, K. \& Piechowski, 1996; Mendaglio, 2008).

During the 50s in the 20th century special afternoon activities for high ability students were not allowed in the USSR, as they contradicted the "Socialist Equity" idea that perceived extra-curricular activities to privileged children as a threat. In addition, as the private sector did not exist officially [...] (Greenberg \& Baron, 1997), [...] parents, along with some other interested acquaintances, organized afternoon private classes in English and science held in their own houses (David, 2009a, p. 38)

Before 1990, gifted and talented children in painting, ballet or music from all over the USSR were sent to Moscow or to St. Petersburg to special schools (Persson et al., 2000). As for mathematics - there had been a few centers for the mathematically gifted.

In her case study, David (2009a) describes at length two of the main characteristics that had influenced education in the ex-USSR before 1990: 1. The lack of "official" education for the gifted, and the constant need of the intellectual community - including parents and teachers of all levels - to have their own "community of knowledge" led to private teaching; 2. The existence of special schools for those with the highest achievements, in spite of their contradicting the "equality scheme" that was the official one. Thus, without any identification processing, children and youths would have gathered in private houses, together with their parents who had belonged to the same milieu - usually an urban intelligentsia - and study literature, or any other area of science or the humanities that had either been banned under the communist government or dismissed as "unimportant", "unnecessary", or "uninteresting".

\section{After 1990}

The very first program adopted by the new Russia was the Munich Model of Giftedness, which started in Moscow in 1989, and the first findings of it were published as early as in 1993. Since then both Russia and the new republics have learnt from the Western experience regarding gifted education. From a psychological point of view, there is no doubt that the students have benefited. The very rigid communist rules that had been applied for young children striving for excellence had had some excellent results in many areas. However, there have not been reliable data about those who were not strong enough emotionally to leave home at a young age, or of others who had dedicated their lives to competitive sport and then found they had no profession at all because they did not fit into the lifestyle required. The application of new theories of giftedness gives hope for many gifted children, who have an opportunity to "make it" under much lesser strain. An example of such an application has been published by Grigorenko (2000).

\section{Starting Teacher Education Courses in all aspects of Giftedness for Kindergarten, Elementary, Junior High School and High School Teachers}

The mixed messages that gifted children receive from their peers, teachers and other adults cause much of the problems in gifted education. Let me start with a short story that will demonstrate this problem.

In many countries, the use of the word "gifted" has negative social connotations, namely, the labeling as "gifted" results in exclusion, sometimes bullying (Peterson, \& Ray, 2006a, 2006b), or even ostracism. This verbal connotation is well known in English spoken countries, where "gifted" has become a synonym of 
"nerd" (e.g. Bilger, 2004; Definitions net, 2011). In my country, where the main official language is Hebrew, a Semitic language based on 3-letter roots which are the building bricks of all verbs and nouns, the adjective "gifted" also contains the tree letters "Het", "Nun", and another "Nun", the same 3 letters that are the roots of my name: Hanna. The meaning of this root is, just like as in English and in German - giving, a gift, or amnesty, mercy - words that by all means symbolize sharing, having good feelings, or forgiving. In spite of this very positive semantic field, one of my in-service training students, a teacher with 30 years of experience, approached me at the end of the first class in the course: "the gifted child in the regular classroom", and said: "I liked your teaching, and the subject is indeed very interesting. But I don't think I can stay in your class. Something really bothers me, and I do not know how to overcome it". "Why don't you just tell me what bothers you?" I asked. She looked around, asked me to come to the corridor with her, and when she was sure nobody was listening she said: "I can't stand the word 'gifted'. I have no explanation, but I am really allergic to it". "Ok", I said. "You will not hear this word in the next class. Whenever I'll have to use it, I'll use the first name: 'Guy'". ${ }^{2}$ And indeed, during the whole 90 minutes of the next class I repeatedly used "Guy" instead of "gifted", but after the class was over the student came to me and said: "I have been ridiculous. Please, from next week do use the word 'gifted"'...

This anecdote demonstrates that even among teachers the world "gifted' has sometimes negative connotations. The situation is no better among less educated people - in fact, we might expect it to be even worse. It seems that the negative attitude of both educators and the public towards the gifted crosses religion and cultural borders. In an interview with Mr. Wagi Balum, the head of the Taibe enrichment program, one of the Israeli programs located in Arab centers and aimed at Arab children, he said: " $98.5 \%$ of the Taibe parents object to the program. Only $1.5 \%$ are in favor of it, in fact - they support it in all possible ways. No wonder only $1.5 \%$ of the Taibe children are accepted - their very proud parents are, of course, my warmest fans; however - I cannot get financial support from the town, because the municipality would not give away money against the wishes of such a massive majority of the citizens" (David, 2006). In spite of public debate about gifted education, any country wishing to nurture its high ability students for their as well as for its own sake should start a gifted education system as soon as the literacy level accelerates and education becomes accessible to everybody. When waiting too long, the high level of resistance gifted education meets might endanger its existence. Such has been the case of Singapore. Singapore was, along with Hong Kong, the highest achiever in the 2007 TIMSS for grade 4 students, and at the top with Korea as well for $8^{\text {th }}$ graders (Mullis et al., 2008); the results of the PISA 2009 in reading, mathematics and science have been similar (OECD, 2010). However, gifted education had started in Singapore as late as in 1984 (Gifted Education Unit, 1994). Due to a high level of resistance, and in spite of the high achievements of its graduates (ibid), in 2008 it was changed in order to include up to percentile 98 or even 95, rather than 99, of the school population (Li, 2007).

In a reality where gifted education is not always accepted by the public, when there is always budget pressure and the educational needs grow beyond the ability to meet them, teacher education courses in all aspects of gifted education are crucial for the success of any program for the gifted. Not only must these courses concentrate on all psychological and didactic aspects of giftedness, but they also have to prepare the teachers for the resistance of the public, for the pressures 'to concentrate on the weak' and for the moral, ethical and philosophical issues connected to special education in general and to a group perceived as "elitist" in particular.

Teaching and educating the gifted courses must be offered to all teachers, as most gifted students, even in countries with a developed system of gifted education, study most of the time in regular classes.

2 Guy is an English as well as Hebrew name with a different meaning. 
Offer Health and Education Experts to Participate in a Variety of Activities for Identifying and Nurturing the Gifted. These Experts will Include Psychologists, School Counselors, Headmasters and Headmistresses, Nurses and Pediatricians.

Learning about giftedness in order to support gifted children and youths includes more than identifying their high level abilities and letting them advance at their own pace in any subject matter they prefer.

When a child first enters the educational system, he or she is not usually given special education for the gifted, even in countries where such education exists (David, 2008). Thus, the school teacher is the first person who must deal with the educational, as well as the psychological, emotional, social and sometimes familial problems of the gifted child. However, while each teacher of special education children must have special training for each learning disability, limitation, physical handicap, blindness or deafness, no training in giftedness is given to the teacher who has, on average, at least one gifted child in each class. In addition, while special education teachers receive in-service training during their years of teaching, no such training is offered to teachers of the gifted, who include practically all teachers...

The role of the school counselor in gifted education has been the focus of many research papers and books aimed at counselors in general and school counselors in particular, as well as educational and clinical psychologists (e.g. Fornia, \& Wiggins Frame, 2001; Lardner, 2005; Milgram, 1991; Moon, 2003; Reis, 2005; Silverman, 1997; Thomas et al., 2007; Wood, 2010). Thus, counseling students who take many classes and seminars in a variety of subjects, in addition to supervised practical work during their studies, should be offered courses in gifted psychology and gifted education. The exact number of courses taken must be modified according to the available lecturers and instructors each higher education institution can supply, but in any case it must include a minimum of the following:

a. Introduction: The gifted child. Educational, psychological social, and familial aspects;

b. The gifted child in the regular classroom.

c. Special programs for the gifted.

d. Reading contemporary literature in theory and practice of gifted education.

In addition, each counselor should take a cluster of classes and seminars that would serve him or her for the sub-population of the gifted he or she intends to work with. For example: the gifted kindergartner; gifted adolescents; gifted females; gifted with learning disabilities, or mathematically gifted childrenor adolescents.

\section{Building a Dynamic Evaluation System that will Produce and Supply Advancement Reports at Every Stage of the Work, in Order to be Able to Make the Needed Changes Immediately in Case the Results or Outcomes do not Reach the Highest Possible Levels.}

After choosing the most appropriate basic system for identification of the gifted and deciding on the best possible way to nurture them, all educators and psychologists involved must take into consideration that the process had by no means reached any stable level. One of the means needed in order to have the most appropriate system both for identification and nurturing the gifted is adopting a dynamic valuation system (Heller, 2004; Kanevsky, 2000; Lidz, \& Elliott, 2006). Dynamic assessment consists, in most cases, of a testintervene-retest structure, aimed to improve the student's performance when an adult provides mediated assistance on how to master the testing task. When a system is dynamic, it can change whenever necessary in order to take into consideration the multidimensional conceptions of giftedness, rather than treating giftedness as narrowed down to cognitive abilities, artistic talents or extra-ordinary social skills.

A dynamic system is of special importance for the underachieving gifted, gifted from economically or culturally disadvantaged backgrounds, or gifted with disabilities (Calero et al., 2011; Kaniel, 2010; Kaniel, \& Reichenberg, 1990; Kirschenbaum, 1998; Lidz, \& Macrine, 2001). A dynamic assessment provides means for assessing students who have had no experience in ability tests, whose culture is focused on cooperative rather than competitive values (David \& Wu, 2009b), and students who are tested in a language which is not 
their mother tongue and thus need either more time for completing the tasks or some explanations in order to be sure they have understood the directions. Of special importance is assessing of gifted disabled students (e.g. David, 2009b, 2010, 2011).

\section{Conclusion}

In order to build an effective system for identification and nurturing of the gifted it is highly recommended to learn as much as possible from the experience of other countries in this area. However, whatever seems to be the most suitable program, the following must be taken into consideration:

1. No existing program will be "hand tailored" for the Nigerian gifted children, and thus changes must be made before adopting any programs;

2. After starting working with the chosen program, constant changes should be made, according to the needs;

3. Only a continuing process of evaluation and re-examination can ensure the success and promotion of the program

\section{References}

Australian Department of Education and Early Childhood development (2011). Retrieved on 22 January 2011 from http://www.education.vic.gov.au/studentlearning/programs/gifted/

Barrington, B.L. (1968). Special education students - How many are misplaced? Journal of Learning Disabilities, 1, 726-729.

Bilger, B. (July 26, 2004). Annals of Childhood, "Nerd Camp". The New Yorker, p. 64.

Burks, B.S., Jensen, D.W. and Terman, L.M. (1930). The promise of youth. Volume 3: Genetic studies of genius. Stanford, California: Stanford University Press.

Calero, M.D., G.M.M. Belen, \& Robles, A. (2011). Learning Potential in high IQ children: The contribution of dynamic assessment to the identification of gifted children. Learning and Individual Differences, In Press, Corrected Proof, Available online 16 Dec. 2010.

Central Intelligence Agency (CIA) Report (2010). Retrieved on January 162011 from https://www.cia.gov/library/publications/the-worldfactbook/fields/2103.html

Chessman, A. (2005). Policy development and practice: The New South Wales experience International Education Journal, $6(2), 156$.

Cooper, B.S., \& Sureau, J. (2007). The politics of homeschooling: New developments, new challenges. Educational Policy, 21, $110-131$.

Dabrowski, K. (1964). Positive disintegration. Boston: Little Brown \& Co.

Dabrowski, K. \& Piechowski, M. M. (with Marlene [Rankel] and Dexter R. Amend). (1996). Multilevelness of emotional and instinctive functions. Part 2: Types and Levels of Development. Lublin, Poland: Towarzystwo Naukowe Katolickiego Uniwersytetu Lubelskiego.

David, H. (2006). The Taibe enrichment program for gifted children: How is it different from similar programs in the Jewish sector? The $37^{\text {th }}$ conference of the Israeli Sociological Union Society: Sociology, Ethics and Politics, Bar llan University, Israel, 22nd-23rd February 2006.

David, H. (2008). Integration or separate classes for the gifted? The Israeli view. Australasian Journal of Gifted Education, 17(1), 40-47.

David, H. (2009a). Giftedness and immigration: Case study of a gifted family emigrating from Russia to Israel. Australasian Journal of Gifted Education, 18(1), 37-47.

David, H. (2009b). The crystallization of the self of a gifted dyslexic young boy after forced dextralization. In H. David, \& E. Wu, Understanding Giftedness: A Chinese-Israeli Casebook (pp. 113-143). Hong Kong: Pearson Education South Asia.

David, H. (2009c). "Gifted education in Hong Kong and Israel: Comparative study. Conference on Excellence in Education 2009: Leading Minds Creating the future. Ulm, Germany, 24th-27th August 2009.

David, H. (2010). Gifted Case Studies. In A. İşsman \& Z. Kaya (eds.), International Conference on New Horizons in Education: Proceedings book (pp. 7-23). Famagusta, Cyprus, 23rd-25th June 2010.

David, H. (2011). Learning disabilities, AD[H]D, and giftedness: Two case-studies. Gifted Education Press, Summer 2011.

David, H., \& Wu, E. (2009a). Understanding Giftedness: A Chinese-Israeli Casebook. Hong Kong: Pearson Education South Asia.

David, H., \& Wu, E.H (2009b). What is there to be learnt from the presented case-studies? In H. David, \& E. Wu, Understanding Giftedness: A Chinese-Israeli Casebook (pp. 194-211). Hong Kong: Pearson Education South Asia

Definitions net (2011). Retrieved on 16 January 2011 from http://www.definitions.net/definition/nerd

Fornia, G.L. \& Wiggins Frame, M. (2001). The social and emotional needs of gifted children: Implications for family counseling. The Family Journal, 9, 384-390.

Gagné, F. (1999). Is there light in the end of the tunnel: Gagné's Differentiated Model of Giftedness and Talent. Journal for the Education of the Gifted, 22, 191-234. 
Gagné, F. (2004). Transforming gifts into talents: the DMGT as a developmental theory. High ability studies, 15, (2), 119-147.

Gagné, F. (2009). Building gifts into talents: Detailed overview of the DMGT 2.0. In B. MacFarlane, \& T. Stambaugh, (Eds.), Leading change in gifted education: The festschrift of Dr. Joyce VanTassel-Baska (eds.) (pp. 61-80). Waco: TX: Prufrock. Boston: Allyn and Bacon.

Gifted Education Unit (1994). Gifted Education in Singapore - The first Ten Years. Singapore. Gifted Education Unit, Ministry of Education.

Gifted Education Programme (GEP) - Secondary Level (2011). Retrieved on 16 January 2001 from Ministry of Education, Singapore http://www.moe.gov.sg/education/programmes/gifted-education-programme/secondary/

Greenberg, J., \& Baron, R.A. (1997). Behavior in Organizations: Understanding and Managing the Human Side of Work, 6th ed. Upper Saddle River, NJ: Prentice-Hall.

Grigorenko, E.K. (2000). Russian gifted education in technical disciplines. In K.A. Heller, F.J. Mönks, R.J. Sternberg, \& R.F. Subotnik (2000). (Eds.), International handbook of research and development of giftedness and talent (2nd ed.) (pp. 735-742). Oxford: Elsevier.

Gross, M.U.M. (2003). Exceptionally Gifted Children (2nd ed.). London: Routledge.

Hartley, M. (1996). Reading and literature. In D. McAlpine, \& R. Moltzen (Eds), Gifted and talented: New Zealand perspectives (pp. 253272). Palmerston North, New Zealand: Educational Research and Development Center, Massey University.

Heller, K.A. (2004). Identification of Gifted and Talented students. Psychology Science, 46(3), 302-323.

Heller, K.A. (2005). The Munich Model of Giftedness and Its Impact on Identification and Programming. Gifted and Talented International, 20, 30-36.

Heller, K.A., Perleth, Ch. \& Lim, T.K. (2005). The Munich Model of Giftedness designed to identify and promote gifted students. In R.J. Sternberg \& J.E. Davidson (Eds.), Conceptions of Giftedness (2nd ed., pp. 147-170). New York: Cambridge University Press.

Heller, K.A., \& Schofield, N.J. (2000). International trends and topics of research on giftedness and talent. In K.A. Heller, F.J. Mönks, R.J., Sternberg, \& R.F. Subotnik (eds.), International handbook of research and development of giftedness and talent (2nd ed.) (pp. 123-140). Oxford: Elsevier.

Heller, K.A. \& Schofield, N.J. (2008). Identification and nurturing the gifted from an international perspective. In S.I. Pfeiffer (Ed.). Handbook of giftedness in children: Psychoeducational theory, research, and best practices (pp. 93-114). New York: Springer.

Hollingworth, L.S. (1926). Gifted Children: Their nature and nurture. New York: The Macmillan Company.

Hollingworth, L.S. (1942). Children above 180 IQ Stanford-Binet: Origin and development. Yonkers-on-Hudson, NY: World Book.

Janos, P. (1987). A fifty year follow-up of Terman's youngest college students and IQ-matched age mates. Gifted Child Quarterly, 31(2), 55-58.

Kanevsky, L. (2000). Dynamic assessment of gifted students. In K.A. Heller, F.J. Mönks, R.J., Sternberg, \& R.F. Subotnik (eds.), International handbook of research and development of giftedness and talent (2nd ed.) (pp. 283-296). Oxford: Elsevier.

Kaniel, S. (2010). Domain specific vs domain general: Implications for dynamic assessment. Gifted Education International, 26, 93-107.

Kaniel, S. \& Reichenberg, R. (1990). Dynamic assessment and cognitive programs for disadvantaged gifted children. Gifted Education International, 7(1), 9-15.

Kirschenbaum, R.J. (1998). Dynamic assessment and its use with underserved gifted and talented populations. Gifted Child Quarterly, 42(3), 140-147.

Landesgymnasium Sankt Afra (2011). Retrieved on 17 January 2011 from http://www.sankt-afra.de/

Lardner, C. (2005). School counselors light-up the intra- and inter-personal worlds of our gifted. Journal of Personality and Social Psychology, 82, 663-674.

Leroux, K.A. (2000). A study of education for high ability students in Canada. Policy, programs and student needs. In K.A. Heller, F.J. Mönks, R.J., Sternberg, \& R.F. Subotnik,_International handbook of research and development of giftedness and talent (2nd ed.) (pp. 695-702). Oxford: Elsevier.

Li, H.-A.- (3/11/2007). Gifted scheme kids to mix more with others. Retrieved on 18 January 2011 from the Straits Times http://www.straitstimes.com/Free/Story/STIStory_173174.html

Lidz, C.S., \& Elliott, J.G. (2006). Use of dynamic assessment with gifted students. Gifted Education International, 21, 151-161.

Lidz, C.S., \& Macrine, S. (2001). Identification of minority and immigrant students for gifted education: The contribution of dynamic assessment. School Psychology International, 22 (1), 74-96.

Lih, K.W., \& Anku, S.E. (1996). A teacher's perspective of the gifted education programme in Singapore. Paper presented to the Australian Association for Research in Education Conference, Sydney 1996. Retrieved on January 202011 from http://www.aare.edu.au/96pap/kohw196409.txt

Linzer Schwartz, L. (1994). Why Give "Gifts" to the Gifted? Thousand Oaks, CA: Corwin Press.

Marland, S.P., Jr. (1972). Education of the gifted and talented: Report to the Congress of the United States by the U.S. Commissioner of Education and background papers submitted to the U.S. Office of Education, 2 vols. Washington, DC: U.S. Government Printing Office. (Government Documents Y4.L 11/2: G36)

McAlpine, D. (1996). Concepts and definitions. In D. McAlpine, \& R. Moltzen (Eds), Gifted and talented: New Zealand perspectives. Palmerston North, New Zealand: ERDC Massey University.

Mendaglio, S. (Ed.). (2008). Dabrowski's Theory of Positive Disintegration. Scottsdale AZ: Great Potential Press, Inc.

Milgram, R.M. (1991) (Ed.). Counseling Gifted and Talented Children: A Guide for Teachers, Counselors, and Parents. New York, NY: Barnes \& Noble. 
Ministry of Education. (2000). Gifted and talented students: Meeting their needs in New Zealand schools. Wellington, New Zealand: Learning Media.

Mönks, F.J. \& Pflüger, R. (2005). Gifted Education in 21 European Countries: Inventory and Perspective. Nijmegen, The Netherlands: Radboud University.

Moon, S.M. (2003). Family counseling with the Gifted. In N. Colangelo \& G. Davis (Eds.), Handbook of gifted education ( $3^{\text {rd }}$ Ed.) (pp. 388-402). Boston, MA: Allyn \& Bacon.

Mullis, I.V.S., Martin, M.O., \& Foy, P. (with Olson, J.F., Preuschoff, C., Erberber, E., Arora, A., \& Galia, J.). (2008). TIMSS 2007 International Mathematics Report: Findings from IEA's Trends in International Mathematics and Science Study at the Fourth and Eighth Grades. Chestnut Hill, MA: TIMSS \& PIRLS International Study Center, Boston College.

Oden, M.H. (1968). The fulfillment of promise: 40-year follow-up of the Terman gifted group. Genetic Psychology Monographs, 77, 2-92.

OECD (2010). PISA 2009: Volume I, What Students Know and Can Do: Student Performance in Reading, Mathematics and Science, compares the knowledge and skills of students across countries. Retrieced on January 1282011 from http://browse.oecdbookshop.org/oecd/pdfs/browseit/9810071E.PDF

Paddock, R.C. (30/7/1995). The Secret IQ Diaries. Los Angeles Times/ Retrieved on 18 January 2011 from http://articles.latimes.com/1995-07-30/magazine/tm-29325_1_lewis-terman/5

Perleth, C. \& Heller, K.H. (1994). The Munich Longitudinal Study of Giftedness. In R.F. Subotnik \& K. Arnold (eds.), Beyond Terman: Contemporary Longitudinal Studies of Giftedness and Talent (pp, 77-114). Norward, NJ: Ablex.

Persson, R. S., Balogh, L., \& Joswig, H. (2000). Gifted education in Europe: Programs, practices, and current research. In K.A. Heller, F.J. Mönks, R.J. Sternberg, \& R.F. Subotnik (Eds.), International handbook of research and development of giftedness and talent (2nd ed.) (pp. 703-734). Oxford: Elsevier.

Peterson, J.S, \& Ray, K.E. (2006a). Bullying and the Gifted: Victims, Perpetrators, Prevalence, and Effects. Gifted Child Quarterly, 50(2), 148-169. [Peterson 2006.Pdf]

Peterson, J.S., \& Ray, K.E. (2006b). Bullying Among the Gifted: The Subjective Experience. Gifted Child Quarterly, 50(3), $252-270$. [Petersen And Ray.Pdf]

Reichert, B. (12/2/2007). "Keine neue Sorte Mensch". Retrieved on 25 August 2010 from the Stern web: http://www.stern.de/wissenschaft/mensch/:Hochbegabte-Keine-Sorte-Mensch/582419.html

Reis, S.M. (2005). External barriers experienced by gifted and talented girls and women. In S.K. Johnsen \& J. Kendrick (Eds.), Teaching and Counseling Gifted girls (pp. 9-30). Waco, TX: Prufrock Press. Silverman, L.K. (1993). Counseling families. In L.K. Silverman (Ed.), Counseling the gifted and talented (pp. 151-178). Denver, CO: Love.

Renzulli, J.S. (1978). What Makes Giftedness? Reexamining a Definition. Phi Delta Kappan, 60(3), 180-184, 261.

Renzulli, J.S. (1986). The three ring conception of giftedness: A developmental model for creative productivity. In R. J. Sternberg \& J. E. Davidson (Eds.), Conceptions of giftedness (pp. 53-92). New York: Cambridge University Press.

Renzulli, J.S. \& Reis, S.M. (1985). The schoolwide enrichment model: A comprehensive plan for educational excellence. Mansfield Center, CT: Creative Learning Press.

Renzulli, J.S. \& Reis, S.M. (1994). Research related to the Schoolwide Enrichment Model. Gifted Child Quarterly, 38, 2-14.

Renzulli, J.S. \& Reis, S.M. (1997). The schoolwide enrichment model: A how-to guide for educational excellence. Mansfield Center, CT: Creative Learning Press.

Sanders, M. (1994). Bethlehem College policy on learners with special abilities. Tauranga, New Zealand: Bethlehem College.

Seagoe, M.V. (1975). Terman and the gifted. Los Altos, CA: W. Kaufmann.

Sears, R.R. (1977). Sources of life satisfaction of the Terman gifted men. American Psychologist, 32, 119-128.

Sears, R.R. (1984). The Terman gifted children study. In S.A. Mednick, M. Hanway, \& K.M. Finello (Eds.), Handbook of longitudinal research. Volume 1: Birth and childhood cohorts. New York, NY: Praeger.

Sears, P.S. \& Barbee, A.H. (1975). Career and life satisfaction among Terman's gifted women. In J. Stanley, W. George \& Solano (Eds.) The gifted and_creative: A fifty-year perspective. Baltimore, MD: Johns Hopkins University Press.

Shavinina, L. (2009) (ed.). International Handbook on Giftedness. Chicago: IL: Springer Science.

Shurkin, J.N. (1992). Terman's kids: The groundbreaking study of how the gifted grow up. New York: Little Brown \& Co.

Silverman, L.K. (1997). Family counseling with the gifted. In N. Colangelo \& G. A. Davis (Eds.), Handbook of gifted education (2nd Ed., pp. 382-395). Needham Heights, MA: Allyn \& Bacon.

Stanley, J. (1990). Leta Hollingworth's Contributions to Above-Level Testing of the Gifted. Roeper Review, 12(3), 166-171.

Sternberg, R.J. (1985). Beyond IQ: A Triarchic Theory of Intelligence. Cambridge: Cambridge University Press.

Sternberg, R.J. (1997). A Triarchic View of Giftedness: Theory and Practice. In N. Coleangelo \& G. A. Davis (Eds.), Handbook of Gifted Education (pp. 43-53). Boston, MA: Allyn and Bacon.

Sternberg, R. J. \& Davidson, J.E. (2005). Conceptions of Giftedness (2nd ed.), Cambridge University Press.

Teo, C.T., \& Quah, M.L. (1999). The Knowledge, Volition and Action Programme in Singapore: The effects of an experimental intervention programme on high ability achievement. High Ability Studies, 10(1), 23-35.

Tannenbaum, A.K. (1983). Gifted Children: Psychological and Educational Perspectives . New York: Macmillan.

Terman, L.M. (1925). Mental and physical traits of a thousand gifted children. Genetic studies of genius, vols. 1 \& 2. Stanford: Stanford.

Terman, L.M. (1930). The promise of youth. Genetic studies of genius, vol. 3, Stanford: Stanford UP.

Terman. L.M. (1954a). The discovery and encouragement of exceptional talent. American Psychologist, 9, 221-230.

Terman, L.M. (1954b). Scientists and non-scientists in a group of 800 gifted men. Psychological Monographs, 68(7), 1-44. 
Terman, L.M. (1959). The gifted group at mid-life. Genetic studies of genius, vol. 5, Stanford: Stanford UP.

Terman, L.M. \& Oden, M.H. (1935). The promise of youth. Genetic studies of genius, vol. 3. Stanford: Stanford UP.

Terman, L.M. \& Oden, M.H. (1947). Genetic studies of genius. vol. 4: The Gifted Child Grows Up: Twenty-five years' follow-up of a superior group. Stanford UP, Stanford CA.

Terman, L.M., \& Oden, M.H. (1951). The Stanford studies of the gifted. P. Witty (Ed.), The gifted child (pp. 20-46). Boston: D.C. Heath.

Terman, L.M. \& Oden, M.H. (1954). Major Issues in the Education of Gifted Children. Journal of Teacher Education, 5(3), $230-232$.

Terman, L.M., Sear, L.C., Sears, P.S., \& Hastorf, A. (1990). Terman Life Cycle Study of Children with High Ability, 1922-1986. Retrieved on 28 November 2010 from http://hdl.handle.net/1902.1/00882 Herausgeber Louis M. Terman, Albert Hastorf Archiv Dataverse Network repository (United States)

The Terman Study (n.d.). The Mega Foundation. Retrieved on 28 November 2010 from http://hiqnews.megafoundation.org/Terman_Summary.htm

Thomas, V., Ray, K., \& Moon, S.M. (2007). Counseling gifted individuals and their families: A systems perspective. In S. Mendaglio \& J. Peterson (Eds.). Counseling the gifted (pp. 29- 95). Waco, TX: Prufrock Press.

Townsend, M.A. (1996). Enrichment and acceleration: Lateral and vertical perspectives in provisions for gifted and talented children. In D. McAlpine, \& R. Moltzen (Eds), Gifted and talented: New Zealand perspectives (pp. 361-176). Palmerston North, New Zealand: Educational Research and Development Center, Massey University.

Vondráková, E., \& Palková, M. (2007). STaN and gifted children education: Experience, Policy, Plans, Cooperation. In S. Verbić (Ed.), Proceedings of the NYEX Conference on Science Education of Gifted Students (pp. 109-113). Pentica Science Center, Serbia, October 18-21 2007.

Vosslamber, A. (2002). Gifted readers: Who are they, and how can they be served in the classroom? Gifted Child Today, 25(2), 14-20. Wollam, J. (1992). Equality versus Excellence: The South Korean Dilemma in Gifted Education. Roeper Review 14(4), $212-217$.

Wolf, T.H. (1969). The emergence of Binet's conceptions and measurement of intelligence: A case history of the creative process. Part II. Journal of the History of Behavioral Sciences, 5(3), 507-537.

Wood, S. (2010). Best practices in counseling the gifted in schools: What's really happening? Gifted Child Quarterly, 54(1), 42-58.

Wu, E.H. (2009). The light at dawn: Professional development on gifted education in Hong Kong. Asia Pacific Journal of Gifted and Talented Education, 1(1), 1-8 